Fikroh : Jurnal Pemikiran dan Pendidikan Islam

Volume. 12, Number. 2, Juli 2019

p-ISSN : 2087-7501, e-ISSN : 2715-4459

Hlm : 130-148

Journal Home Page : https://jurnal.stai-alazharmenganti.ac.id/index.php/fikroh

\title{
UPAYA MENINGKATKAN MINAT DAN HASIL BELAJAR SISWA MENGGUNAKAN MODEL KOOPERATIF TIPE MAKE A MATCH PADA MATA PELAJARAN QURAN HADIST KELAS IV DI MI DARUL ULUM LEMAH PUTIH WRINGINANOM GRESIK
}

\author{
Muhammad Mahfud \\ STAI Al-Azhar Menganti, Gresik, Indonesia \\ muhammadmahfud@gmail.com
}

\begin{abstract}
The effective learning model is a comerstone of learning practices that make it easy for students to learn and give students knowledge, values and skills. One learning model is the Make a match type cooperative learning model. Make a match gives students the opportunity to ask questions, have opinions and interact with students who are active in class. The teacher acts as a facilitator. Make a match model is a technique to find a partner using a card that contains the answers to these questions. Therefore, learning the Quran badith makes it easy for students to memorize the meanings and verses of the Holy Qur'an, one of them by the method of Make a match. The focus of this research is on: a) How is the application of the Make a match cooperative learning model? b) What is the student's interest in learning? c) What are the student learning outcomes? and d) What is the response of students?. This type of research uses Classroom Action Research, a means for researching, perfecting and evaluating the implementation of teacher assignments. The method for initiating this research data, observation sheets, tests and questionnaires. The results of this study indicate that the interests and learning outcomes of students of the Quran hadith subjects in class IV students are said to be still lacking, indicated by the results of observations in class IV students from pre-cycle $61.15 \%$, after the first cycle of $74.07 \%$ and the second cycle increased $85.00 \%$. The application of the Make a match type of cooperative learning model for grade IV students at MI Darul Ulum, Wringinom Gresik, was positive because it was seen from the questionnaire percentage of $88 \%$. With this method, student learning outcomes from pre-cycle of $61.15 \%$ then increased by $73.9 \%$ in the first cycle and beld the second cycle increased by $80.5 \%$ seen from an increase in each ycle of student learning outcomes has been maximized because it exceeds the target Minimum completeness criteria (KKM). The learning
\end{abstract}


implementation procedure using the Make a match method has been running smoothly and in accordance with the planned learning implementation (RPP).

Keywords: Interests, Learning outcomes, Cooperative learning models, Make a match, Quran hadith.

\begin{abstract}
Abstrak
Model pembelajaran efektif merupakan landasan praktik pembelajaran yang memudahkan siswa belajar dan memberi pengetahuan, nilai dan keterampilan pada diri siswa. Salah satu model pembelajarannya adalah model pembelajaran kooperatif tipe Make a match. Make a match memberikan kesempatan pada siswa untuk bertanya, berpendapat serta berinteraksi dengan siswa yang menjadikan aktif dalam kelas. Guru berperan sebagai fasilitator. Model Make a match adalah teknik mencari pasangan menggunakan kartu yang berisi jawaban dari pertanyaan-pertanyaan tersebut. Oleh karenanya, pembelajaran quran hadist memudahkan siswa menghafal arti dan ayat-ayat suci Al-Qur'an, salah satunya dengan cara metode Make a match. Fokus penelitian ini pada: a) Bagaimana penerapan model pembelajaran kooperatif tipe Make a match? b) Bagaimana minat belajar siswa? c) Bagaimana hasil belajar siswa? dan d) Bagaimana respon siswa?. Jenis penelitian ini menggunakan Penelitian Tindakan Kelas, sarana untuk meneliti, menyempurnakan dan mengevaluasi pelaksanaan tugas guru. Metode untuk mengawali data penelitian ini, lembar observasi, tes dan angket. Hasil penelitian ini menunjukkan bahwa minat dan hasil belajar siswa mata pelajaran quran hadist pada siswa kelas IV dikatakan masih kurang, ditunjukkan dengan hasil observasi pada siswa kelas IV dari prasiklus $61,15 \%$, setelah diadakan siklus I sebesar $74,07 \%$ dan siklus II meningkat sebesar $85,00 \%$. Penerapan model pembelajaran kooperatif tipe Make a matchpada siswa kelas IV di MI Darul Ulum pasinan Wringinanom Gresik dikatakan positif karena dilihat dari prosentase angket sebesar 88\%. Dengan metode tersebut, hasil belajar siswa dari pra siklus sebesar 61,15\% kemudian mengalami peningkatan sebesar $73,9 \%$ pada siklus I dan diadakan siklus II meningkat sebesar 80,5\% dilihat dari peningkatan di setiap siklus hasil belajar siswa telah maksimal karena melebihi target Kriteria Ketuntasan Minimal (KKM). Adapun prosedur pelaksanaan pembelajaran dengan menggunakan metode Make a match telah berjalan lancar dan sesuai dengan rencana pelaksanaan pembelajaran (RPP) yang telah direncanakan.
\end{abstract}

Kata kunci: minat, hasil belajar, model pembelajaran kooperatif, Make a match, quran hadist.

\title{
A. Pendahuluan
}

Pendidikan Islam merupakan salah satu proses pengembangan potensi kreatif peserta didik untuk menjadi manusia yang beriman dan bertaqwa kepada Allah, kepribadian pancasila, terampil, cerdas, berbudi luhur, bertanggung jawab terhadap dirinya, bangsa dan Negara serta agama. Dalam proses pendidikan juga mempunyai tujuan diantaranya 
Upaya Peningkatan Minat dan Hasil Belajar...

menggali dan mengembangkan potensi iman atau fitrah manusia dan membentuk manusia yang berakhlak mulia. Menurut pengamatan peneliti permasalahan yang guru hadapi ketika pembelajaran berlangsung di kelas 4 adalah dalam masalah pengelolaan kelas, hal ini disebabkan kesukaran dalm penyajian materi atau belum tepat dalam memilih metode. Ada beberapa siswa yang ketika guru menyampaikan pelajaran hanya melamun dan diam tanpa bertanya sehingga sisa terkesan kurang menyenangkan dalm proses pembelajaran. Guru hanya menggunakan metode ceramah atau Terangkan Catat Latihan (TCL) di depan kelas tanpa ada keterlibatan siswa secara langsung. Dalam pembelajaran Quran Hadist cenderung merupakan pelajaran yang kurang diminati siswa. Kondisi ini menunjukkan bahwa, pada kenyataannya guru dalam kegiatan belajar mengajar di kelas cenderung satu arah, artinya guru hanya mentransformasikan ilmu pengetahuannya dan siswa tinggal menerima model pembelajaran, seperti ini menyebabkan pembelajaran berpusat pada guru dan siswa dijadikan objek belajar bukan subjek belajar dan siswa terkesan kurang semangat dalam menerima pelajaran dan jikalau tidak ada minat belajar siswa, maka hasil belajarnya menjadi rendah dengan kata lain siswa banyak yang tidak mencapai standart ketuntasan.

Dalam penelitian ini, penyusun meneliti tentang bagaimana meningkatkan minat dan hasil belajar siswa dalam proses belajar melalui model pembelajaran kooperatif tipe make a match dalam pembelajaran quran hadist kelas IV di MI Darul Ulum Lemah Putih Wringinanom. Sekolah MI Darul Ulum Lemah Putih Wringinanom adalah setingkat sekolah dasar yang bercirikan agama islam. Sekolah ini merupakan sekolah yang sedang berkembang untuk meningkatkan mutu pendidikan, peningkatan mutu pendidikan merupakan komitmen bersama yang harus dipegang teguh. Apalagi melihat dari sekolah MI Darul Ulum Lemah Puth Wringinanom adalah sekolah agama di mana mengedepankan mata pelajaran agama islam namun meskipun begitu tetap memberikan aktu yang seimbang untuk mata pelajaran umum. Oleh karena itu berusaha untuk melahirkan generasi yang bukan hanya mampu hidup tetapi juga mampu bertahan hidup dan dapat bermanfaat dalam kehidupan masyarakat.

Penelitian ini guna membahas mengenai, Bagaimana penerapan model kooperatif tipe Make a Match pada siswa kelas IV pada mata pelajaran Quran Hadist di MI Darul Ulum Lemah Putih Wringinanom Gresik? Bagaimana minat belajar siswa kelas IVpada 
mata pelajaran Quran Hadist melalui penerapan model kooperatif tipe Make a Matchdi MI Darul Ulum Lemah Putih Wringinanom Gresik? Bagaimana hasil belajar siswakelas IVpada mata pelajaran Quran Hadist melalui penerapan model kooperatif tipe Make a Matchdi MI Darul Ulum Lemah Putih Wringinanom Gresik?.

\section{B. Metode Penelitian}

Penelitian ini merupakan Penelitian Tindakan Kelas (PTK) dalam bahasa inggris yaitu Classroom Action Research, yang berarti action research yakni penelitian yang dilakukan di kelas. ${ }^{1}$ Penelitian tindakan kelas merupakan suatu pencermatan terhadap kegiatan yang sengaja dimunculkan dan terjadi dalam sebuah kelas. Adapun menurut Hasley penelitian tindakan adalah intervensi dalam dunia nyata serta pemeriksaan terhadap pengaruh yang ditimbulkan dari intervensi tersebut. ${ }^{2}$ Dari berbagai definisi PTK dapat diartikan sebagai proses pengkajian masalah pembelajaran di dalam kelas melalui refleksi diri dalam upaya untuk memecahkan masalah tersebut dengan cara melakukan berbagai tindakan yang terencana dalam situasi yang nyata serta menganalisis setiap pengaruh dari perlakuan tersebut. ${ }^{3}$ Metode yang digunakan adalah Model Kooperatif tipe Make a Match. Tujuan suatu penelitian dalam proses pembelajaran atau disebut dengan Penelitian Tindakan Kelas (PTK) ini untuk memunculkan kendala-kendala apa yang menyebabkan proses pembelajaran tidak tepat pada sasaran, sebagaimana dirasakan di kelas 4 MI Darul Ulum Pasinan Lemah Putih Wringinanom Gresik, pada mata pelajaran Quran Hadist.

\section{Hasil dan Pembahasan}

Hipotesis berasal dari dua kata yaitu "Hypo" yang artinya dibawah dan "Thesa" yang artinya kebenaran, jadi hipotesis yang kemudian cara menulisnya disesuaikan dengan ejaan Bahasa Indonesia menjadi hipotesa, dan berkembang menjadi hipotesis. Apabila peneliti telah mendalami permasalahan penelitiannya dengan seksama serta menetapkan anggapan dasar, kemudian membuat suatu teori sementara, yang kebenarannya masih perlu diuji (dibawah kebenaran). Adapun hipotesis tindakan yang peneliti ajukan adalah: (1) Hipotesis kerja $\left(\mathrm{H}_{\mathrm{a}}\right)$ : Ada peningkatan minat dan hasil belajar siswa setelah menggunakan model

1Suyadi, Panduan Penelitian Tindakan Kelas (Jogjakarta: Diva Press, 2010), 17.

${ }^{2}$ Wina Sanjaya, Penelitian Tindakan Kelas (Jakarta: Kencana, 2009), 20.

${ }^{3}$ Suyadi, Panduan Penelitian Tindakan Kelas, 22. 


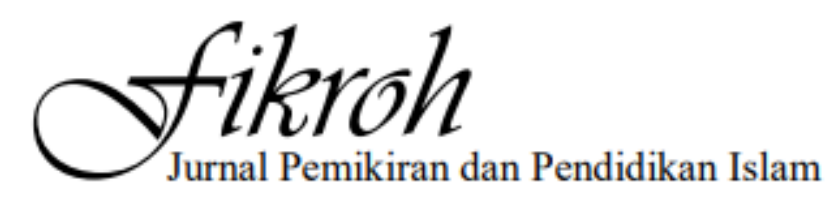

Upaya Peningkatan Minat dan Hasil Belajar...

kooperatif tipe make a match pada mata pelajaran quran hadist kelas IV di MI Darul Ulum Wringinanom Gresik. (2) Hipotesis nol $\left(\mathrm{H}_{0}\right)$ : Tidak ada peningkatan minat dan hasil belajar siswa setelah menggunakan model kooperatif tipe make a match pada mata pelajaran quran hadist kelas IV di MI Darul Ulum Wringinanom Gresik.

Subyek yang dijadikan sumber data dalam penelitian ini adalah siswa kelas IVdi MI Darul Ulum Pasinan Lemah Putih Wringinanom Gresik pada semester genap, pada tahun pelajaran 2018-2019. Jumlah keseluruhan kelas IV ada 20 siswa yang terdiri dari 7 siswa laki-laki dan 13 siswa perempuan. Jadwal penelitian ini dilaksanakan sesuai dengan jadwal mata pelajaran Quran Hadist yang telah ditetapkan di MI Darul Ulum pasinan lemah putih Wringinanom Gresik. Penelitian ini pada mata pelajaran Quran Hadist dengan pokok bahasan "Surah Al-Lahab dan Surah Al-Insyirah" dan dilaksanakan pada tanggal 26 maret 2019 dan 30 maret 2019 untuk siklus 1 yang dilaksanakan pada hari selasa dan sabtu, dan untuk siklus 2 dilaksanakan 2 april 2019 pada hari selasa. Penelitian ini melibatkan guru mata pelajaran Quran Hadist sebagai kolaborasi untuk membantu dalam pemantauan proses pembelajaran. Model yang peneliti gunakan adalah model yang dikemukakan oleh Kemmis \& Mc Taggart. Adapun model pendekatan tindakan kelas (PTK) ini dimaksud untuk menggambarkan adanya empat langkah (dan pengulangannya), apabila digambarkan dalam bentuk visualisasi maka akan tergambar dalam bagan seperti berikut ini: ${ }^{4}$

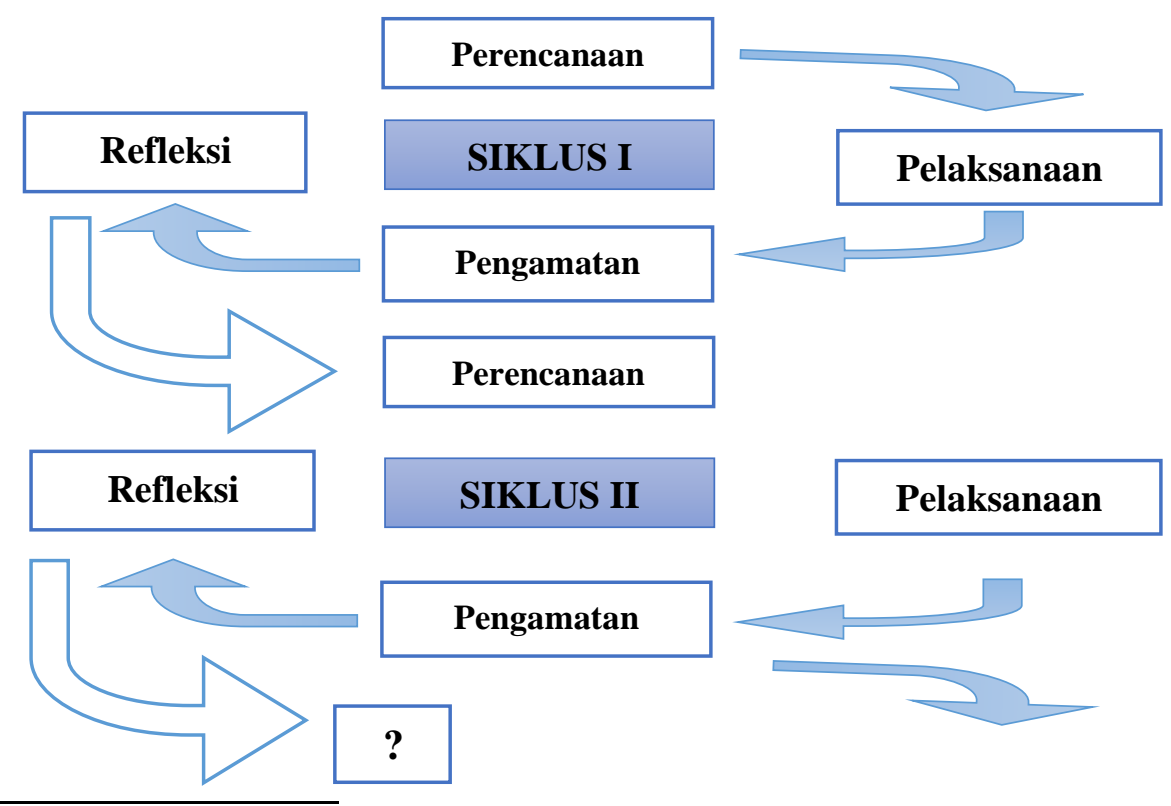

${ }^{4}$ Suharsimi Arikunto, Prosedur Penelitian Suatu pendekatan Praktik (Jakarta: Rineka Cipta, 2013), 137. 
Gambar. 1 Bagan model PTK

Penelitian dilaksanakan dengan menerapkan empat kegiatan pokok, yakni perencanaan, pelaksanaan, pengamatan dan refleksi. Untuk memperoleh gambaran lengkap tentang rancangan penelitian tindakan kelas ini, berikut dapat diuraikan lebih lanjut. Pada penelitian ini menggunakan penelitian tindakan kelas dimana peneliti ingin menerapkan model pembelajaran kooperatif tipe Make a Match pada pembelajaran mata pelajaran Quran Hadist dengan tujuan meningkatkan minat dan hasil belajar siswa pada mata pelajaran Quran Hadist. Penelitian Tindakan Kelas ini dilaksanakan dengan dua siklus, yaitu:

\section{Siklus $I$.}

Pelaksanaan pembelajaran setiap siklus I ini terdiri dari tahapan perencanaan, pelaksanaan atau tindakan, observasi dan refleksi.

a. Tahap Perencanaan.

Perencanaan dalam setiap siklus disusun perencanaan pembelajaran untuk perbaikan pembelajaran. Dengan demikian, dalam perencanaan bukan hanya berisi tentang tujuan atau kompetensi yang harus dicapai akan tetapi juga harus lebih ditonjolkan perlakuan khususnya oleh guru dalam proses pembelajaran, ini berarti perencanaan yang disusun harus dijadikan pedoman seutuhnya dalm proses pembelajaran. ${ }^{5}$

Pada tahapan perencanaan, peneliti mempersiapkan RPP, media yang digunakan untuk memudahkan siswa dalam memahami materi yang akan disampaikan, lembar observasi dan lembar penilaian. Namun sebelum diadakan siklus, terlebih dahulu diadakan evaluasi prestasi siswa sebelum menggunakan model pembelajaran Kooperatif tipe Make a Match untuk mengetahui hasil belajar siswa.

b. Tahap Pelaksanaan atau Tindakan.

Pada tahap tindakan ini adalah perlakuan yang dilaksanakan oleh peneliti berdasarkan perencanaan yang telah disusun. ${ }^{6}$ Pelaksanaan perbaikan pembelajaran merupakan salah satu tahap dimana proses penelitian yang sistematis dan terncana. Pada tahap pelaksanaan, kegiatan pelaksanaan yang dilakukan dalam kegiatan pembelajaran

${ }^{5}$ Wina Sanjaya, Penelitian Tindakan Kelas, 69.

'Wina Sanjaya, Penelitian Tindakan Kelas, 69. 
disesuaikan dengan apa yang sudah ditulis dalam persiapan rencana pelaksanaan pembelajaran (RPP) yang telah dibuat sebelumnya (terlampir). Tindakan inilah yang menjadi initi dari penelitian tindakan kelas, sebagai upaya meningkatkan kinerja guru untuk menyelesaikan masalah.

c. Tahap Pengamatan atau observasi.

Pada tahap ini peneliti mengamati selama terjadinya proses pembelajaran, sehingga dapat diketahui hasil dari presentase per kelompok dan observer mengamati peneliti serta menilai peneliti dalam proses pembelajaran berlangsung. Observasi ini dilakukan untuk mengumpulkan informasi tentang proses pembelajaran yang guru sesuai dengan tindakan yang telah disusun. Data yang dikumpulkan berupa data kuantitatif (hasil tes, nilai tugas dan lain-lain) tetapi juga data kualitatif yang menggambarkan keaktifan siswa, kemampuan siswa dan kesiapan siswa.

d. Tahap Refleksi

Refleksi adalah aktivitas melihat berbagai kekurangan yang dilaksanakan oleh guru selama tindakan. Refleksi dilakukan dengan melakukan diskusi dengan observer yang biasanya dilakukan oleh teman sejawat. Pada tahap ini dimaksudkan untuk mengkaji secara menyeluruh tindakan yang telah dilakukan, berdasarkan data yang telah terkumpul dan kemudian melakukan evaluasi guna menyempurnakan tindakan berikutnya. Dalam tahap ini, hasil pengamatan dalam observasi didiskusikan sebagai bahan refleksi untuk rencana tindakan pada siklus kedua. Jika peneliti belum mencapai kriteria 75\% maka peneliti masuk ke dalam siklus II.

\section{Siklus II}

Tahapan-tahapan diisi sesuai dengan temuan pada refleksi pada siklus sebelumnya. (a) Tahap perencanaan, (b) Tahap pelaksanaan, (c) Tahap pengamatan, (d) Tahap refleksi. Adapun siklus berhenti apabila minat belajar siswa dikategorikan positif sebesar $75 \%$, apabila proses pembelajaran dikatakan baik dan berhasil jika mencapai $75 \%$ dari jumlah nilai hasil belajar siswa yang memenuhi Kriteria Ketuntasan Minimal (KKM) dan apabila secara klasikal hasil belajar siswa mencapai 80\%. 
Dalam kegiatan belajar mengajar guru menggunakan metode ceramah, sehingga siswa mudah bosan, mudah mengantuk dan kurang berminat untuk membangun dan menemukan sendiri konsep-konsep yang penting dalam materi. Dalam menyampaikan materi pelajaran guru jarang menggunakan model pembelajaran. Oleh karena itu peneliti menggunakan model pembelajaran kooperatif tipe make a match yang sangat mengutamakan adanya keaktifan siswa. Peneliti melakukan perbaikan tindakan dengan mengembangkan perangkat pembelajaran yang meliputi: (1) Mengembangkan dengan membuat RPP; (2) Membuat lembar soal; (3) Menyusun instrument penelitian; (4) Lembar pengamatan minat belajar siswa; (5) Lembar kemampuan guru mengelola pembelajaran menggunakan model kooperatif tipe Make a Match; (6) Angket respon siswa

Teknik analisis data yang digunakan dalam penelitian ini adalah analisa deskriptif yakni analisa dengan penggambaran suatu penelitian dalam bentuk angka, tabel, persentase, dan sebagainya untuk menjelaskan tujuan penelitian. Pada lembar validasi perangkat pembelajaran ini, validator menuliskan penilaiannya terhadap masing-masing perangkat terdiri dari RPP, Penilaian hasil belajar dan lembar observasi. Penilaian terdiri dari 4 kategori, yakni kategori 1, 2, 3, dan 4 yaitu tidak baik, kurang baik, baik dan sangat baik. Proses analisis dimulai dengan menghitung nilai rata-rata yang diberikan oleh tiap-tiap validator untuk setiap aspek dengan rumus sebagai berikut:

\section{Rata - rata validitas $=\frac{\text { jumlah skor pengamatan }}{\text { banyak butir pengamatan }}$}

Nilai rata-rata $(x)$ ini dibandingkan dengan selang kriteria pada tabel 3.1 di bawah ini:

Tabel 3.1 kriteria validitas perangkat pembelajaran

\begin{tabular}{cl}
\hline \multicolumn{1}{c}{ Skor nilai } & \multicolumn{1}{c}{ Kriteria } \\
\hline $1,00 \leq \mathrm{VP}<1,75$ & Tidak baik \\
$1,75 \leq \mathrm{VP}<2,50$ & Kurang baik \\
$2,50 \leq \mathrm{VP}<3,50$ & Baik \\
$3,50 \leq \mathrm{VP} \leq 4,00$ & Sangat baik
\end{tabular}

Hasil analisis tersebut disajikan sebagai pedoman untuk merevisi perangkat pembelajaran. Perangkat pembelajaran dapat digunakan (valid) jika validator memberikan penilaian dengan kategori minimal baik, Kalau tidak maka perlu direvisi. 
1. Analisis Data Observasi (pengamatan)

a. Data minat belajar siswa

Data hasil observasi adalah hasil pengamatan aktivitas siswa dengan mendeskripsikan setiap indikator penilaian minat siswa setelah pemberian materi pembelajaran model kooperatif tipe Make a match. Data hasil pengamatan tersebut kemudian dianalisis menggunakan rumus:

Aktivitas Siswa $=\frac{\text { Jumlah skor tiap aspek }}{\text { Jumlah keseluruhan skor }} x 100 \%$

Presentase Aktivitas siswa dideskripsikan sebagai berikut:

$0 \% \leq$ Aktivitas Siswa $<50 \% \quad$ : Kurang Baik

$50 \% \leq$ Aktivitas Siswa $<75 \% \quad$ : Baik

$75 \% \leq$ Aktivitas Siswa $<100 \% \quad$ : Sangat Baik

Aktivitas siswa dikatakan baik jika semua aspek yang dinilai berada pada kategori sangat baik atau baik.

b. Data kemampuan guru mengelola pembelajaran.

Pada kegiatan proses belajar mengajar setelah guru menerapkan dan mengelola model pembelajaran koopertif tipeMake a match, ini digunakan untuk mengetahui kegiatan guru selama proses pembelajaran berlangsung. Tingkat Kemampuan Guru dianalisis menggunakan statistik deskriptif dalam bentuk presentase dihitung dengan rumus:

Kemampuan Guru $=\frac{\text { Jumlah skor tiap aspek }}{\text { Jumlah keseluruhan skor }} x 100 \%$

Presentase Tingkat Kemampuan Guru dideskripsikan sebagai berikut:

$0 \% \leq$ Kemampuan Guru $<25 \% \quad$ : Kurang Baik

$25 \% \leq$ Kemampuan Guru $<50 \% \quad$ : Cukup Baik

$50 \% \leq$ Kemampuan Guru $<75 \% \quad$ : Baik

$75 \% \leq$ Kemampuan Guru $\leq 100 \% \quad$ : Sangat Baik

c. Analisis Data Angket Respon Siswa.

Data respon siswa dianalisis menggunakan statistika deksriptif dalam bentuk presentase, dihitung dengan rumus sebagai berikut: 
Respon siswa $=\frac{\text { Jumlah } \text { siswa } \text { yang } \quad \text { menjawab }}{\text { jumlah seluruh siswa }} \times 100 \%$

Dengan kriteria presentase respon siswa dideskripsikan sebagai berikut:

$0 \% \leq$ Respon Siswa $<55 \% \quad$ : Kurang Baik

$56 \% \leq$ Respon Siswa $<75 \% \quad$ : Baik

$76 \% \leq$ Respon Siswa $<100 \% \quad$ : Sangat Baik

Respon siswa dikatakan positif apabila semua aspek yang dinilai berada pada kategori setuju atau minimal kurang setuju.

d. Analisis Data Penilaian Belajar Siswa

Data penilaian belajar siswa dianalisis secara statistik deskriptif bertujuan untuk mendeskripsikan ketuntasan penilaian belajar siswa. Setiap siswa dikatakan tuntas belajarnya (secara individu) jika penilaian belajar yang diperoleh siswa lebih dari atau sama dengan KKM yang telah ditentukan oleh sekolah yaitu 75. Ketuntasan individu dihitung dengan rumus sebagai berikut:

Nilai Hasil Belajar $=\frac{\text { Jumlah skoryang diperoleh }}{\text { Jumlah skor maksimal }} \times 100 \%$

Selanjutnya, suatu kelas dikatakan tuntas secara klasikal jika $80 \%$ dari seluruh siswa di kelas tersebut telah mencapai nilai minimal KKM. Analisis yang dilakukan untuk menghitung presentase ketuntasan hasil belajar siswa secara klasikal adalah:

$\mathrm{P}=\frac{\sum \mathrm{n} 1}{\sum \mathrm{n}} \times 100 \%$

$\mathrm{P} \quad=$ Nilai ketuntasan belajar klasikal

$\Sigma \mathrm{n} 1=$ Jumlah siswa tuntas belajar individual

$\Sigma \mathrm{n} \quad=$ Jumlah total siswa

2. Model Pembelajaran Kooperatif

Model pembelajaran adalah suatu pola yang digunakan sebagai pedoman kepada siswa yang harus diketahui, dimengerti, dan dipahami dalam melaksanakan pembelajaran kelas atau dalam pembelajaran tutorian dan untuk menentukan perangkat-perangkat pembelajaran termasuk di dalamnya buku-buku, film, komputer, kurikulum dan lain-lain. ada beberapa ciri-ciri model pembelajaran secara khusus diantaranya: 
a. Rasional teoritik yang logis yang disusun oleh para pencipta atau pengembangnya.

b. Landasan pemikiran tentang apa dan bagaimana siswa belajar.

c. Tingkah laku mengajar yang diperlukan agar model tersebut dapat dilaksanakan dengan berhasil.

d. Lingkungan belajar yang diperlukan agar tujuan pembelajaran dapat tercapai.

Pemilihan model pembelajaran yang akan digunakan sangat berpengaruh terhadap tingkat keberhasilan belajar siswa. Adapun tujuan metode pembelajaran kooperatif ini, yaitu: (1) Untuk meningkatkan hasil belajar akademik, (2) Mengajarkan siswa untuk menerima perbedaan dan keragaman, (3) Mengembangkan keterampilan sosial. Di dalam pembelajaran kooperatif terdapat elemen-elemen, yaitu: (1) Saling ketergantungan positif, (2) Akuntabilitas individual, (3) Interaksi tatap muka, (4) Keterampilan menjalin hubungan

Menurut Roger dan David, metode pembelajaran koopeatif dibagi menjadil lima, yaitu: (1) Positive interdependence, (2) Personal responsibility, (3) Face to face promotive interavtion, (4) Interpersonal skill, (5) Group processing. Macam-macam Model Pembelajaran Kooperatif, (1) Metode STAD (Student Achievement Divisions), (2) Metode jigsaw, (3) Metode G (Group Investigation), (4) Metode struktural memiliki beberapa teknik pembelajaran, yaitu: Make a match, Bertukar pasangan, Berkirim salam dan soal, Bercerita berpasangan, Think-Pair-Share, Numbered heads together, Bamboo dancing, Point-Counter-Point, The power of two, Listening team.

\section{Metode Pembelajaran Make a Match}

Model pembelajaran Make a Match ini dikembangkan pertama kali pada tahun 1994 oleh Lorna Curran, strategi make a matchsaat ini menjadi salah satu strategi penting dalam ruang kelas. ${ }^{7}$ Model pembelajaran make a matchadalah kartu-kartu. Kartu-kartu tersebut terdiri dari kartu yang berisi pertanyaan dan kartu yang lainnya berisi jawaban dari pertanyaan-pertanyaan tersebut. ${ }^{8}$ Di samping itu make a match juga memberikan kesempatan kepada siswa untuk bertanya dan mengeluarkan pendapat serta berinteraksi

${ }^{7}$ Miftahul Huda, Model-model Pengajaran dan Pembelajaran (Yogyakarta: Pustaka Pelajar, 2013), 251.

${ }^{8}$ AgusSuprijono, Cooperatif Learning Teori \& Aplikasi Paikem, 94. 


\section{Muhammad Mahfud}

dengan siswa yang menjadikan aktif dalam kelas dan guru lebih berperan sebagai fasilitator. Persiapan yang dilakukan sebelum melakukan model pembelajaran Make a Match adalab:

a. Membuat beberapa pertanyaan yang sesuai dengan materi yang dipelajari kemudian menulisnya dalam kartu-kartu pertanyaan.

b. Membuat kunci jawaban dari pertanyaan-pertanyaan yang telah dibuat dan menulisnya dalam kartu-kartu jawaban.

c. Membuat aturan yang berisi penghargaan bagi siswa yang berhasil dan memberi sanksi bagi siswa yang gagal. Dan semua aturan ini dapat membuat bersama dengan siswa.

d. Menyediakan lembaran untuk mencatat pasangan-pasangan yang berhasil sekaligus untuk penskoran prestasi (penilaian).

Strategi Make a Match dapat dilihat pada langkah-langkah kegiatan pembelajaran berikut ini:

a. Guru menyampaikan materi atau memberi tugas kepada siswa untuk mempelajari materi di rumah.

b. Siswa di bagi menjadi 2 kelompok, misalnya kelompok A dan kelompok B.

c. Guru membagikan kartu pertanyaan kepada kelompok A dan kartu jawaban kepada kelompok B.

d. Guru menyampaikan kepada siswa bahwa mereka harus mencari atau mencocokkan kartu yang dipegang dengan kartu kelompok lain. Guru juga perlu menyampaikan batasan maksimum waktu yang diberikan kepada siswa.

e. Guru meminta semua anggota kelompok A untuk mencari pasangannya di kelompok B. Jika mereka sudah menemukan pasangannya masing-masing, guru meminta mereka melaporkan dirinya kepadanya. Guru mencatat mereka pada kertas yang sudah dipersiapkan.

f. Jika waktu sudah habis, maka harus diberitahukan kepada siswa bahwa waktu sudah habis. Siswa yang belum menemukan pasangannya diminta untuk berkumpul tersendiri. 
g. Guru memanggil satu pasangan untuk dipresentasekan. Pasangan lain dan siswa yang tidak dapat pasangan memperhatikan dan memberikan tanggapan apakah pasangan itu cocok atau tidak.

h. Terakhir, guru memberikan konfirmasi tentang kebenaran dan kecocokkan pertanyaan dan jawaban dari pasangan yang memberikan presentasi.

i. Guru memanggil pasangan berikutnya, begitu seterusnya sampai seluruh pasangan melakukan presentasi.

Adapun Kelebihan dari Model Pembelajaran Make a Match adalah:

a. Dapat meningkatkan aktivitas belajar siswa, baik secara kognitif maupun fisik.

b. Karena ada unsur permainan, metode ini menyenangkan.

c. Meningkatkan pemahaman siswa terhadap materi yang dipelajari dan dapat meningkatkan motivasi belajar siswa.

d. Efektif sebagai sarana melatih keberanian siswa untuk tampil prestasi.

e. Efektif melatih kedisiplinan siswa menghargai waktu untuk belajar. Sedangkan kelemahan Model Pembelajaran Make a Match

a. Jika strategi ini tidak dipersiapkan dengan baik, akan banyak waktu yang terbuang.

b. Pada awal penerapan metode, banyak siswa yang akan malu berpasangan dengan lawan jenisnya.

c. Jika guru tidak mengarahkan siswa dengan baik, akan banyak siswa yang kurang memperhatikan pada saat presentasi pasangan.

d. Jika menggunakan metode ini secara terus menerus akan menimbulkan kebosanan.

Manfaat Model Pembelajaran Make a Match

a. Dapat memotivasi siswa untuk saling membantu pembelajaran satu sama lain.

b. Menumbuhkan rasa tanggung jawab terhadap kelompoknya.

c. Meningkatkan keterampilan sosial yang dibutuhkan untuk bekerja secara efektif.

d. Dapat mengembangkan bakat kepemimpinan dan mengajarkan menganalisis dan berinteraksi sosial. 
e. Melatih siswa agar lebih cermat dan lebih kuat dalam pemahaman terhadap materi.

\section{Upaya Meningkatkan Minat Belajar}

Secara bahasa minat berarti kecenderungan hati yang tinggi terhadap sesuatu. ${ }^{9}$ Sedangkan pengertian minat secara istilah telah banyak dikemukakan oleh para ahli, diantaranya dikemukakan oleh Sardiman berpendapat bahwa minat merupakan suatu kondisi yang terjadi apabila seseorang melihat ciri-ciri atau arti sementara sityasi yang dihubungkan dengan keinginan-keinginan atau kebutuhan-kebutuhan sendiri. ${ }^{10}$

Menurut Slameto minat adalah suatu rasa lebih suka dan rasa keterikatan pada suatu hal atau aktifis, tanpa adanya menyuruh. ${ }^{11}$ Di dalam minat dapat mempengaruhi intensitas cita-cita dan tenaga pendorong yang kuat untuk mencapai sesuatu yang diinginkan. Minat yang kuat akan menimbulkan usaha yang gigih, serius dan tidak mudah putus asa dalam menghadapi rintangan. Jika seseorang siswa memiliki rasa ingin belajar, ia akan dapat cepat mengerti dan mengingatnya.

Menurut Abd. Rahman Abror seseorang yang dikatakan berminat terhadap sesuatu bila individu itu memiliki beberapa unsur antara lain: Sikap, Kemauan, Ketertarikan, Dorongan, Ketentuan, dan perhatian ${ }^{12}$ Dari keenam unsur minat tersebut dapat dibuat indikator-indikator-indikator yang dapat digunakan dalam pembuatan angket minat sehingga angket yang dibuat mengacu pada unsur-unsur minat yang telah dikembangkan. Menurut Abu Ahmadi ada beberapa hal yang dapat mempengaruhi minat yaitu sebagai berikut: Pembawaan, Kebutuhan, Kewajiban, Suasana jiwa, Keadaan batin, Lingkungan sekitar, Kuat tidaknya perangsang ${ }^{13}$

Salah satu faktor-faktor yang mempengaruhi belajar antara lain mencakup minat, adanya minat terhadap objek yang dipelajari akan mendorong orang untuk mempelajari sesuatu dan mencapai hasil belajar yang maksimal. ${ }^{14}$ Berdasarkan pengamatan pra siklus minat siswa dalam kegiatan belajar mengajar sangat rendah, hasil

${ }^{9}$ Tim Penyusun Kamus Pusat Pengembangan Dan Pembinaan Bahasa, Kamus Besar Bahasa Indonesia (Jakarta: Balai Pustaka, 1990), 583.

${ }^{10}$ Sardiman A.M. Interaksi dan Motivasi Belajar Mengajar, 76.

${ }^{11}$ Slameto, Belajar dan Faktor-faktor Yang Mempengarubinya, 180.

${ }^{12}$ Abd. Rahman Abror, Psikologi Pendidikan (Yogyakarta: PT. Tiara Wacana Yogya, 1989), 136-141.

${ }^{13} \mathrm{Abu}$ Ahmadi, Psikologi Umum (Jakarta: PT. Rineka Cipta, 1991), 17.

${ }^{14}$ Nyayu Khodijah, Psikologi Pendidikan (Jakarta: Rajawali Pers, 2014), 59. 
belajar siswa juga rendah. Hal ini dikarenakan sistem pembelajaran yang masih bersifat monoton atau klasikal. Peneliti dan guru bidang studi bersepakat menggunakan model pembelajaran kooperatif tipe Make a Match pada mata pelajaran Quran Hadist di kelas IV dengan materi Surah Al-Lahab dan Surah Al-Insyirah.

Minat belajar siswa selama pembelajaran menggunakan model pembelajaran kooperatif tipe Make a Match pada siklus I dan siklus II mengalami peningkatan. Hal ini dikarenakan ketika kegiatan belajar mengajar siswa sudah tidak lagi merasa bosan, jenuh ataupun tidak mudah mengantuk, persiapan belajar juga sudah meningkat, selalu memperhatikan guru saat menerangkan materi dan aktif bertanya apabila ada yang kurang faham. Pada siklus I sebesar 74,07\% dimana siswa masih ada yang bingung dan ada yang belum memperhatikan dengan menggunakan model pembelajaran kooperatif tipe Make a Match ini namun guru tetap memberikan arahan secara teliti dan diadakan kembali model pembelajaran tersebut pada berikutnya sehingga siswa mampu menerima dengan baik model dan materi yang diajarkan sehingga siklus II meningkat sebesar 85,00\%. Minat belajar siswa pada siklus I mengalami peningkatan jika dibandingkan dengan pra siklus karena pra siklus atau sebelum tindakan hanya memperoleh $61,15 \%$. Hal ini dikarenakan ketika kegiatan belajar mengajar siswa merasa bosan dan jenuh, tidak ada persiapan belajar, kurang memperhatikan guru ketika guru sedang memberikan arahan atau menerangkan materi pelajaran di depan kelas dan kurang aktif dalam bertanya. Pada siklus I terlihat siswa mulai aktif dan ada yang bertanya jika ada materi yang belum difahami, ada kesiapan belajar dan memperhatikan guru di depan kelas. Pada siklus II siswa lebih aktif dan semangat dalam bertanya, mampu menyimpulkan materi yang diajarkan dan mengerjakan soal dengan baik sesuai dengan harapan guru.

Kemampuan guru dalam belajar mengajar meningkat ketika menggunakan model pembelajaran kooperatif tipe Make a Match dibandingkan dengan sebelum tindakan sebesar 58,33\%. Guru hanya menggunakan model pembelajaran ceramah dan pemberian tugas yang membuat siswa bosan dan tidak berminat untuk mendengarkan. Setelah menggunakan model pembelajaran kooperatif tipe Make a Match kemampuan guru meningkat menjadi 70,83\%. Karena sudah melaksanakan langkah-langkah dalam 
penerapan model pembelajaran ini tapi belum optimal dan belum maksimal masil belum efektif waktu yang dibutuhkan. Pada siklus II iknerja guru lebih baik dan mencapai target yang dinginkan yaitu 85,40\%. Hal ini dikarenakan tidak lepas dari usaha guru dan kerja sama dengan siswa dalam memperbaiki keadaan proses belajar mengajar agar lebih baik.

\section{Upaya Meningkatkan Hasil Belajar}

Evaluasi dan belajar berhubungan sangat erat. Tanpa evaluasi, sulit diketahui apakah usaha belajar yang dilakukan oleh seseorang telah mencapai hasil yang diharapkan. Jadi hasil belajar adalah suatu hasil yang diharapkan dari pembelajaran yang telah ditetapkan dalam rumusan perilaku tertentu.

Untuk mengetahui hasil belajar yang dicapai telah sesuai dengan tujuan yang ditetapkan, diperlukan evaluasi hasil belajar. Evaluasi hasil belajar adalah semua proses dan alat yang digunakan guru untuk membuat keputusan tentang kemajuan belajar yang dicapai siswa. Evaluasi juga mencakup keputusan tentang bagaimana cara mengetahui hasil belajar siswa, kapan melakukannya dan apa saja yang hendak diketahui. ${ }^{15}$ Keberhasilan belajar sangat dipengaruhi oleh beberapa faktor. Faktor-faktor tersebut dikelompokkan menjadi dua kelompok, yaitu:

a. Faktor Internal

Faktor ada pada dalam diri siswa yang berpengaruh terhadap hasil belajar siswa diantaranya adalah kecakapan, minat, bakat, usaha, motivasi, perhatian, kelemahan, kesehatan serta kebiasaan siswa.

b. Faktor Eksternal

Faktor pada luar diri siswa yang mempengaruhi hasil belajar siswa diantaranya adalah lingkungan fisik dan non fisik, lingkungan sosial budaya, lingkungan keluarga, program sekolah, guru, pelaksanaan pembelajaran, dan teman sekolah.

Menurut Puranto, mengatakan bahwa faktor guru dan cara mengajarnya merupakan faktor penting, bagaimana sikap dan kepribadian guru, tinggi rendahnya pengetahuan yang dimiliki oleh guru, dan bagaimana cara guru itu mengajarkan

${ }^{15}$ Nyayu Khodijah, Psikologi Pendidikan, 189-190. 
pengetahuan itu kepada anak-anak didiknya turut menentukan hasil belajar yang akan dicapai oleh siswa. Dengan demikian maka perlu kepada para anak didik ditanamkan kebisaan-kebiasaan baik, agar mendoong tercapainya hasil belajar yang optimal. Kebaisaan baik tersebut sebaiknya dilakukan atau diterapkan oleh guru terlebih dahulu karena guru adalah contoh yang patut ditiru oleh anak didik.

Hasil belajar siswa meningkat terlihat pada siklus I siswa yang tuntas mencapai 73,9\% karena siswa mulai aktif dalam proses pembelajaran. Dan siklus II meningkat sebesar $80,5 \%$ dilihat dari peningkatan di setiap siklus hasil belajar siswa telah maksimal karena mencapai target KKM dalam pelajaran ini adalah 70 dan indikator keberhasilan dalam penelitian tindakan kelas ini merupakan 75\% dari pencapaian sudah tercapai.

Respon siswa terhadap pembelajaran menggunakan model pembelajaran kooperatif tipe Make a Match sangat baik karena dilihat dari angket yang telah diisi oleh para siswa dan hasil prosentase angket rata-rata sebesar 88\% maka sudah dikatakan sangat baik. Dari jawaban siswa tersebut berarti siswa sangat menyukai cara belajar yang bermacam-macam salah satunya dengan menggunakan model pembelajaran kooperatif tipe Make a Match ini.

Dengan demikian pembelajaran menggunakan model pembelajaran kooperatif tipe Make a Match pada materi Surah Al-Lahab dan Surah Al-Insyirah pada mata pelajaran Quran Hadist dikatakan baik karena dapat meningkatkan minat belajar siswa, memotivasi sisawa dan meningkatkan hasil belajar siswa dalam proses belajar mengajar. Guru juga dapat meningkatkan kinerjanya sehingga ada kekompakkan antara guru dan siswa ketika kegiatan belajar mengajar. Pembelajaran Quran Hadist dengan penerapan model pembelajaran kooperatif tipe Make a Match dapat meningkatkan minat dan hasil belajar siswa kelas IV MI Darul Ulum Lemah Putih - Wringinanom - Gresik tahun ajaran 2018/2019.

\section{Simpulan}

Berdasarkan uraian sebelumnya maka peneliti mengambil keputusan sebagai berikut: (1) Dalam penerapan model pembelajaran model kooperatif tipe Make a Matchini yang dilakukan didalam penerapan metode pembelajaran kooperatif tipe Make a Match ini seluruh siswa kelas IV di MI Darul Ulum Lemah Putih Wringinanom Gresik pada siklus I 
dapat menemukan pasangannya dan mempresentasikan di depan kelas, tetapi ada beberapa siswa yang tidak dapat menemukan pasangannya dan ada yang mendapatkan pasangannya akan tetapi hasilnya tidak cocok. Kemudian pada siklus II seluruh siswa dapat menemukan pasangannya akan tetapi ada 2 pasangan yang jawabannya tidak cocok atau tertukar dengan jawaban pasangan lain; (2) Minat belajar siswa kelas IV di MI Darul Ulum Lemah Putih Wringinanom Gresik dapat dikatakan kurang baik, hal ini dapat dilihat dari hasil observasi sebelum tindakan $61,15 \%$. Setelah diadakan tindakan mengalami peningkatan pada siklus I sebesar 74,07\% dan meningkat lagi sebesar 85,00\% pada siklus II; (3) Hasil belajar siswa kelas IV di MI Darul Ulum Lemah Putih Wringinanom Gresik mengalami peningkatan setelah menerapkan model pembelajaran kooperatif tipe Make a Match. Setelah diadakan tindakan mengalami peningkatan sebesar $73,9 \%$ pada siklus I dan diadakan kembali pada siklus berikutnya meningkat menjadi 80,5\% pada siklus II.

Dengan demikian dapat disimpulkan bahwa sebenarnya penerapan model pembelajaran kooperatif tipe Make a Matchini dapat diterapkan dengan baik dan dapat meningkatkan mutu atau kualitas dalam aktivitas belajar mengajar maupun minat belajar siswa di kelas IV di MI Darul Ulum Lemah Putih Wringinanom Gresik.

\section{E. Daftar Pustaka}

Abror, Abd Rahman. Psikologi Pendidikan. Yogyakarta: PT. Tiara Wacana Yogya, 1989.

Ahmadi, Abu. Psikologi Umum. Jakarta: PT Rineka Cipta, 1991.

A.M Sardiman. Interaksi dan Motivasi Belajar Mengajar. Jakarta: Rajawali, 2004.

Arikunto, Suharsimi. Prosedur Penelitian Suatu Pendekatan Praktik. Jakarta: Rineka Cipta, 2013.

Thoha dkk. Reformasi Filsafat Pendidikan Islam. Yogyakarta: Pustaka Pelajar, 1995.

Huda, Miftahul. Model-model Pengajaran dan Pembelajaran. Yogyakarta: Pustaka Pelajar, 2018.

Khadijah, Nyanyu. Psikologi Pendidikan. Jakarta: Rajawali Pers, 2014.

Nana, Sudjana. Dasar-dasar Proses Belajar Mengajar. Bandung: Sinar Baru, 2004.

Rusd, Abidin Ibnu. Pemikiran Al-Ghozali Tentang Pendidikan. Yogyakarta: Pustaka Pelajar, 1998.

Sanjaya, Wina. Penelitian Tindakan Kelas. Jakarta: Kencana, 2017.

Slameto. Belajar dan Faktor-faktor yang mempengarubinya. Jakarta: Rineka Cipta, 2015.

Sudarmanto. Tuntunan Metodologi Belajar. Jakarta: PT Gramedia Widiasarana Indonesia, 1993. 
Sugiyono. Metode Penelitian Pendidikan Pendekatan Kuantitatif Kualitatif ReDD. Bandung: Alfabeta, 2010.

Suprijono, Agus. Cooperative Learning Teori dan Aplikasi PAIKEM. Yogyakarta: Pustaka Pelajar, 2014.

Suyadi. Panduan Penelitian Tindakan Kelas. Yogyakarta: Diva Press, 2013.

Zuhriah, Nurul. Metodologi Penelitian Sosial dan Pendidikan. Jakarta: PT Bumi Aksara, 2001. 